\title{
Histological assessments of intestinal immuno-morphology of tiger grouper juvenile, Epinephelus fuscoguttatus
}

\author{
Mohd Firdaus-Nawi ${ }^{1}$, Mohd Zamri-Saad ${ }^{1 *}$, Nik Yusoff Nik-Haiha ${ }^{2}$, Md Abu Bakar Zuki ${ }^{1}$ \\ and Abd Wahid Mohd Effendy ${ }^{3}$
}

\begin{abstract}
Histological assessments on the intestinal morphology and immunity of tiger grouper juveniles, Epinephelus fuscoguttatus help in determining the earliest age to start an oral vaccination. This study describes the morphological development of the intestinal immunity of tiger grouper of various ages. Clinically healthy tiger groupers were selected and divided into 4 groups of 20 fish per group. Groups 1, 2, 3 and 4 consisted of juveniles of 30, 60, 90 and 120 days old, respectively. The whole intestine was collected and divided into three regions, the anterior, mid and posterior intestine and fixed in 10\% buffered formalin before slides were prepared for microscopic examinations. It was found that the histological structures of the anterior intestine were for absorption of nutrient from digested food particles. The significantly $(p<0.05)$ higher number and length of the intestinal villi and smaller gap between villi were observed in the anterior intestine, which were structures for absorption. Structures of the posterior intestine were for immunity especially the adaptive immunity with included significantly $(p<0.05)$ higher numbers of the lymphoid and goblet cells, and significantly $(p<0.05)$ thicker lamina propria, which were structures for immunity. The mid intestine was the transition structure that involved in both absorption and innate immunity. The results also revealed that leukocytes existed in the lamina propria of 30-days old tiger groupers, an indication that the immune system was present at that particular age.
\end{abstract}

Keywords: Tiger grouper; Intestine histological; Assessment; Immune system

\section{Introduction}

Grouper is a high value cultured marine fish especially in the Southeast Asia countries including Malaysia, Indonesia, Thailand and the Philippines (Liao et al., 2001; Yashiro, 2008). The major cultured species are giant grouper, Epinephelus lanceolatus (Yashiro, 2008), tiger grouper, Epinephelus fuscoguttatus (Sugama et al., 2008), malabar grouper, Epinephelus malabaricus (Yashiro, 2008), orange spotted grouper, Epinephelus coioides (Toledo et al. 1996), humpback grouper, Cromileptes altivelis (Marte, 2003), leopard coralgrouper, Plectropomus leopardus (De Silva, 1998) and hybrid grouper, (Epinephelus lanceolatus X Epinephelus fuscoguttatus). Heemstra and Randall (1993) estimated that $90 \%$ of the world's harvest on marine food is derived from

\footnotetext{
* Correspondence: zamri@vet.upm.edu.my

${ }^{1}$ Faculty of Veterinary Medicine, Universiti Putra Malaysia, Serdang, Selangor 43400, Malaysia

Full list of author information is available at the end of the article
}

artisanal fisheries, which groupers are the major component. According to Food and Agriculture Organization (FAO) (2013), world aqu of (2880saculture production of groupers was around 6000-7000 tones per annum, valued at about USD60 million and the bulk of this production came from wild seed stock due to lack of reared seed that suffered disease problems.

In Malaysia, tiger grouper, Epinephelus fuscoguttatus, also known as brown marbled grouper, is a major cultured marine species. It is considered a popular and high valued aquaculture species and fast growing (Afero et al., 2009). Data from Federal Agricultural Marketing Authority of Malaysia (2013) (FAMA) indicated that grouper species are the major export fish for the year 2010 (MAHA, 2013).

Fish digestive system is slightly differ from mammal. The digestive process has started in the first region that includes the mouth, oral cavity, and pharynx. Then, after 
food is swallowed it will enter the alimentary canal proper and proceeds via the esophagus to the stomach followed by the intestines (Buddington and Kuz'mina, 2000). The main function of fish intestine is to complete the digestive process, which started in the stomach and also to absorb the nutrients from food (Wilson and Castro, 2011). Other than the digestive function, gut of fish also acts as the firstline barrier against infection. Thus, the mucosal layer of the gut creates physical, chemical and cellular protections against pathogen invasions (Ellis, 2001). The goblet cells and the glandular simple columnar epithelial cells secrete mucus, which contains immunological substances such as glycoprotein (Fletcher and Grant, 1968), cytokines (Lindenstrøm et al. 2003), peptides (Cole et al., 1997), lysozyme (Fernandes et al., 2004), lipoprotein (Concha et al., 2003), complement (Dalmo et al., 1997), lectins (Tsutsui et al., 2005), proteases (Aranishi and Mano, 2000) and antibodies (Cain et al., 2000). These substances provide direct or indirect protection against pathogen (Cain et al., 1996). Furthermore, the intestine of fish contains lymphoid cells that secrete antibodies and involve in phagocytosis. The aim of this study is to describe the histological evaluation on the intestinal immune-morphology of tiger grouper, Epinephelus fuscoguttatus juveniles.

\section{Materials and methods}

\section{Fish and rearing conditions}

A total of 80 healthy tiger grouper (Epeniphelus fuscoguttatus) juveniles of different ages were used. They were 30, 60, 90 and 120 days old of approximately $1 \mathrm{~g} \pm 0.3 \mathrm{~g}, 2.5 \mathrm{~g} \pm$ $0.3 \mathrm{~g}, 200 \mathrm{~g} \pm 0.3 \mathrm{~g}$ and $300 \mathrm{~g} \pm 0.3 \mathrm{~g}$ body weight, and of approximately $2.5 \mathrm{~cm} \pm 0.5 \mathrm{~cm}, 5 \mathrm{~cm} \pm 0.5 \mathrm{~cm}, 7.5 \mathrm{~cm} \pm$ $0.5 \mathrm{~cm}$ and $10 \mathrm{~cm} \pm 0.5 \mathrm{~cm}$ in length, respectively. The selected juveniles were grouped according to the age with 20 fish per group and kept separately in 100-L glass tanks. Fish of less than 30 days old were too small for handling and sampling. All the fish were acclimatized for at least 7 days prior to experiment. Light cycle was held constant with 12 hours of lighting per day. Feeding was ad libitum with a local commercial feed while water was continuously aerated. The water temperature, $\mathrm{pH}$, salinity and dissolved oxygen were measured daily using the HQ40d Meter (Hach Company, Loveland, CO). The ammonia, sulfate and nitrites were determined daily using the DR 2800 Portable Spectrophotometer (Hach Company, Loveland, CO). Prior to sampling, five fish from each age group were sacrificed and swab samples from the organs were collected for bacterial and parasitic examinations. This was to ensure that the fish were free from bacterial and parasitic diseases (Firdaus-Nawi et al., 2012).

\section{Experimental design}

At the start of the experiment, the remaining fifteen juvenile tiger groupers from each group were euthanized by an overdose of Ethyl 3-aminobenzoate methanesulfonate (Sigma Aldrich, USA). Post-mortem examination was performed immediately; the entire intestine was removed and was cut into the anterior, mid and posterior portions (Wilson and Castro, 2011) before the intestinal samples were fixed into $10 \%$ buffered formaldehyde for at least $24 \mathrm{~h}$. The Animal Care and Use Committee of University Putra Malaysia approved the study protocol.

\section{Sample preparation and histological analysis}

Following $24 \mathrm{~h}$ fixation, the samples were prepared for histological examination according to Firdaus-Nawi et al. (2012). The slides were examined under a light microscopy using Nikon NIS-Element D 3.2 Image Analyzer (Nikon Instruments Inc., USA). For each slide, a total of five microscopic fields were examined at $200 \times$ magnification to determine the number of villi, the length of villi, the gap between villi, the thickness of lamina propria, the number of lymphoid cells, the number of goblet cells and the thickness of muscular layer. The Nikon NIS-Element D 3.2 Image Analyzer (Nikon Instruments Inc., USA) was used to measure all parameters.

\section{Statistical analysis}

The Statistix 9 (Analytical Software, USA) was employed to analyze the data. The results revealed significance in all pairwise comparison under one-way ANOVA. Significant differences were determined at $\mathrm{P}<0.05$. Pearson correlation test was used to reveal the correlation between each studied parameters.

\section{Results}

Number of villi

There were significant $(\mathrm{p}<0.05)$ differences in the numbers of villi in the three regions of intestine (Figure 1). The average number of villi of anterior intestine was $39.200 \pm$ $6.1435, \quad 64.467 \pm 11.077, \quad 74.333 \pm 11.709$ and $95.533 \pm$ 4.0860 for tiger groupers at 30, 60, 90 and 120 days old, respectively. The average number of villi of mid intestine was $22.533 \pm 3.6227,49.933 \pm 2.8149,57.867 \pm 6.8334$ and $62.000 \pm 8.000 \mu \mathrm{m}$ at $30,60,90$ and 120 days old, respectively. The average number of villi of posterior intestine was $29.067 \pm 5.1195,43.333 \pm 4.7006,44.533 \pm$ 3.3989 and $51.467 \pm 4.8236 \mu \mathrm{m}$, respectively.

The number of villi was highest in the anterior region of intestine (Figure 2), followed by the mid region and least in the posterior region, except for the 30 days old tiger grouper that showed that the number of villi was significantly $(\mathrm{p}<0.05)$ higher in the posterior than the mid region. In general, the number of villi showed gradual and significant $(\mathrm{p}<0.05)$ increase with the increasing age of the tiger groupers. However, there was no significant $(p>0.05)$ increase in the numbers of villi in the mid intestine between 90 and 120 days old tiger grouper. 


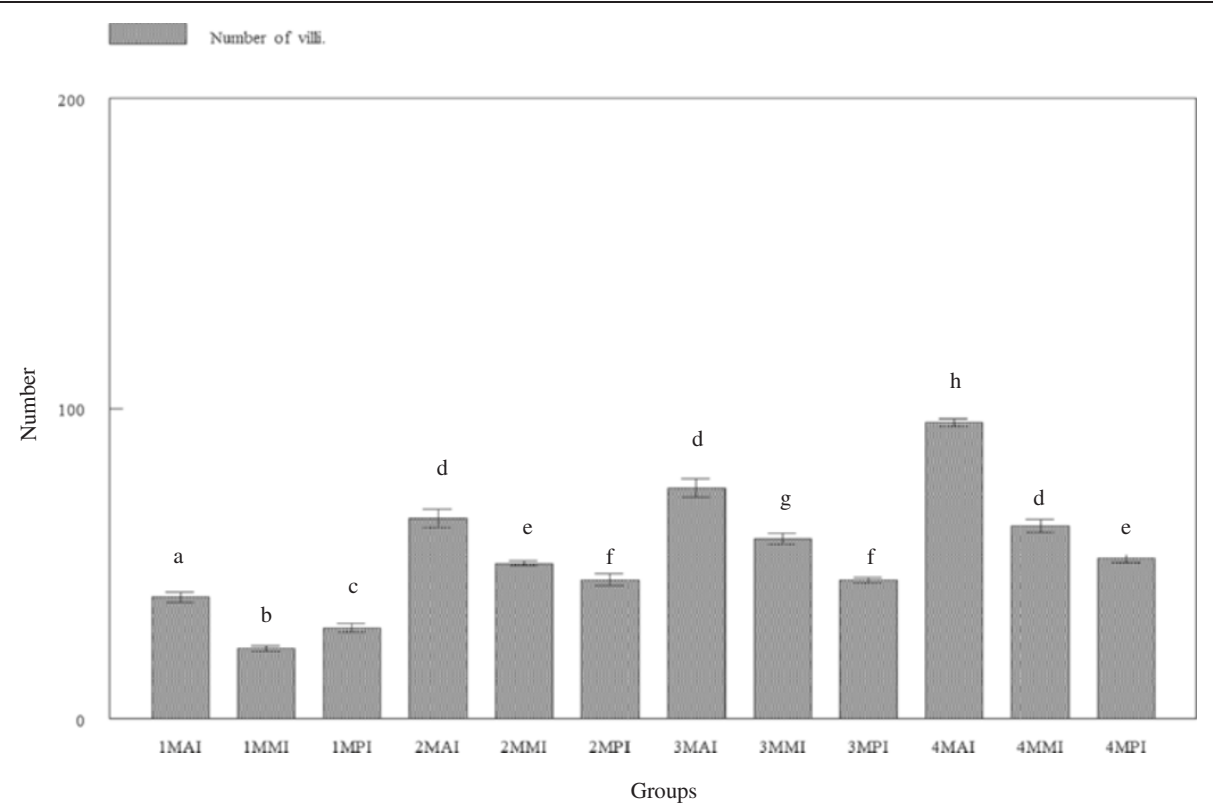

Figure 1 Number of villi in three regions of tiger grouper intestine; anterior intestine (AI), mid intestine (IM) and posterior intestine $(\mathrm{PI})$, in four experimental ages; 30 days $(1 \mathrm{M}), 60$ days $(2 \mathrm{M}), 90$ days $(3 \mathrm{M})$ and 120 days $(4 \mathrm{M})$.

Similar observation was noted for the posterior region of the 60 and 90 days old tiger grouper (Figure 1).

\section{Length of villi}

Measurements of the length of villi revealed significant $(\mathrm{p}<0.05)$ differences between the intestinal regions of all group tiger groupers (Figure 3). The average length of villi at the anterior intestine was $117.08 \pm 23.509$, $234.75 \pm 42.025, \quad 356.21 \pm 59.268$ and $400.55 \pm 31.133$ $\mu \mathrm{m}$ for tiger groupers of 30,60, 90 and 120 days old, respectively. The average length of villi at the mid intestine was $89.094 \pm 10.205, \quad 189.96 \pm 34.111, \quad 215.03 \pm$ 34.326 and $365.99 \pm 39.110 \mu \mathrm{m}$ at $30,60,90$ and 120 days old, respectively. The average number of villi at the posterior intestine was $60.605 \pm 20.576,143.03 \pm$ $35.463,185.31 \pm 59.198$ and $265.44 \pm 46.064 \mu \mathrm{m}$, respectively. For all groups, the length was significantly $(\mathrm{p}<0.05)$ highest in the anterior region, followed by mid

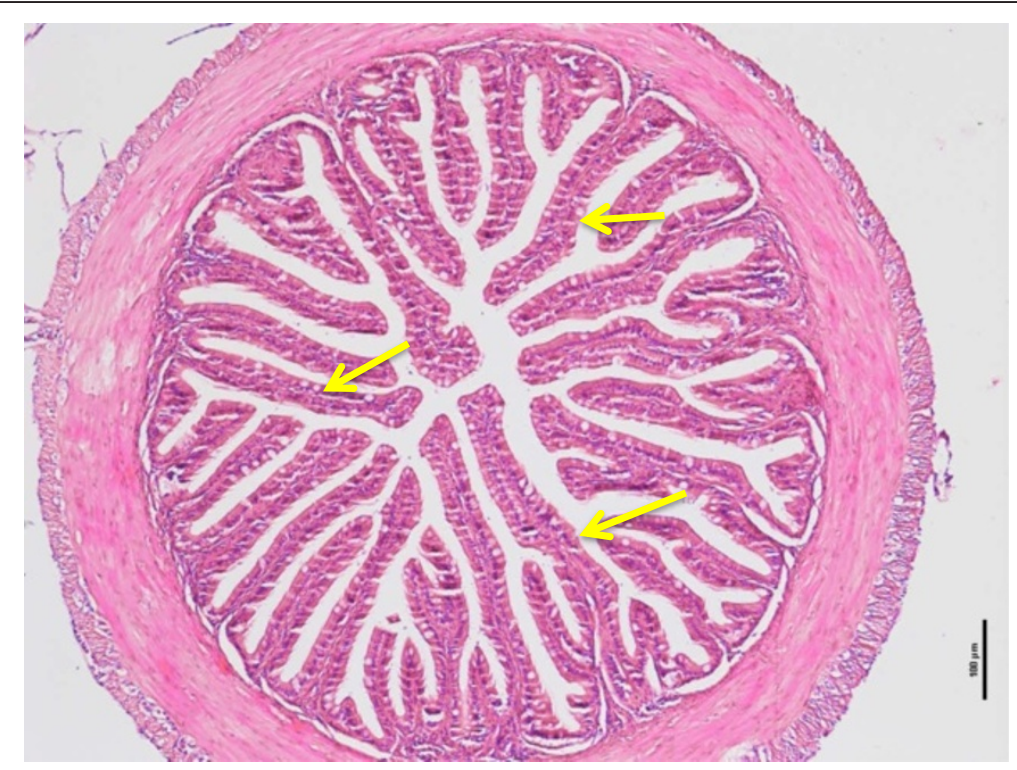

Figure $\mathbf{2}$ Cross-section of anterior intestine of $\mathbf{9 0}$ days old tiger grouper. High numbers of villi were observed (arrows) and it is important to make the absorption process very effective (H\&E x10). 


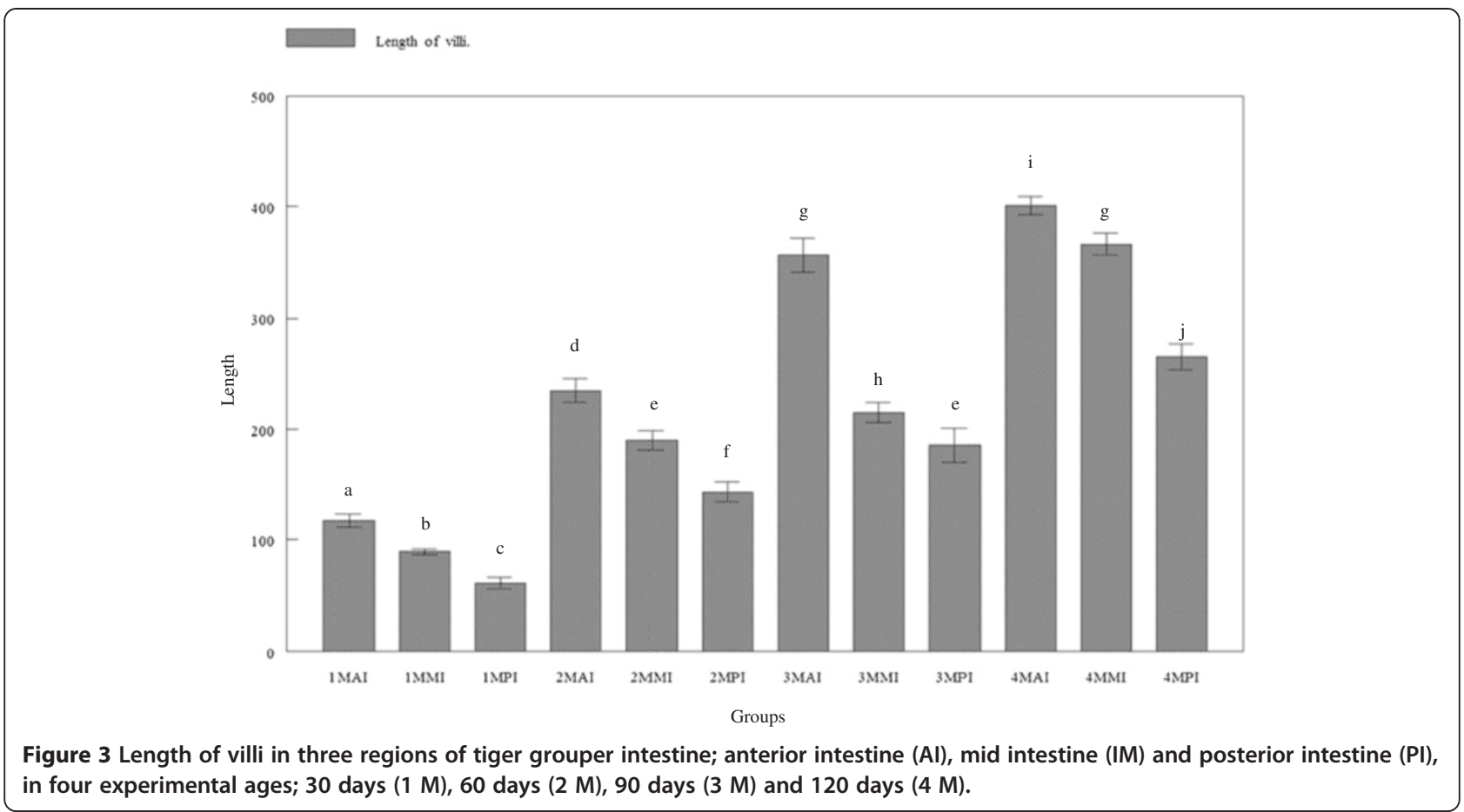

region and least in the posterior intestine. Nevertheless, the length showed gradual increase with increasing age of the tiger groupers (Figures 3 and 4).

\section{Gap between villi}

Widest villus gap was observed in the posterior intestine followed by the mid and the smallest gap was in the anterior intestine (Figures 5 and 6). The average gap between villi of the anterior intestine was $30.143 \pm 4.0889$, $16.756 \pm 2.7046,14.665 \pm 2.3584$ and $13.606 \pm 2.292 \mu \mathrm{m}$ for tiger grouper at 30, 60, 90 and 120 days old, respectively. The average gap between villi of the mid intestine was $41.690 \pm 7.2816, \quad 27.275 \pm 5.5747, \quad 21.957 \pm 4.9491$ and $21.888 \pm 2.9411 \mu \mathrm{m}$ at $30,60,90$ and 120 days old,

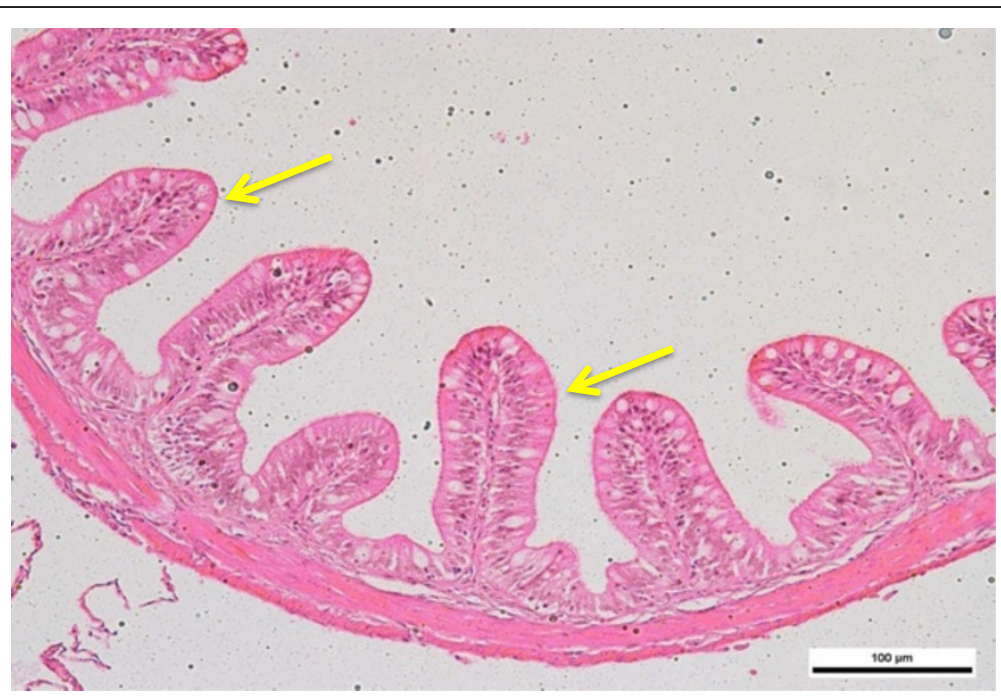

Figure $\mathbf{4}$ Cross-section of posterior intestine of $\mathbf{9 0}$ days old tiger grouper. The villi in posterior region is shortest compared to in mid and anterior intestine (arrows) (H\&E x20). 


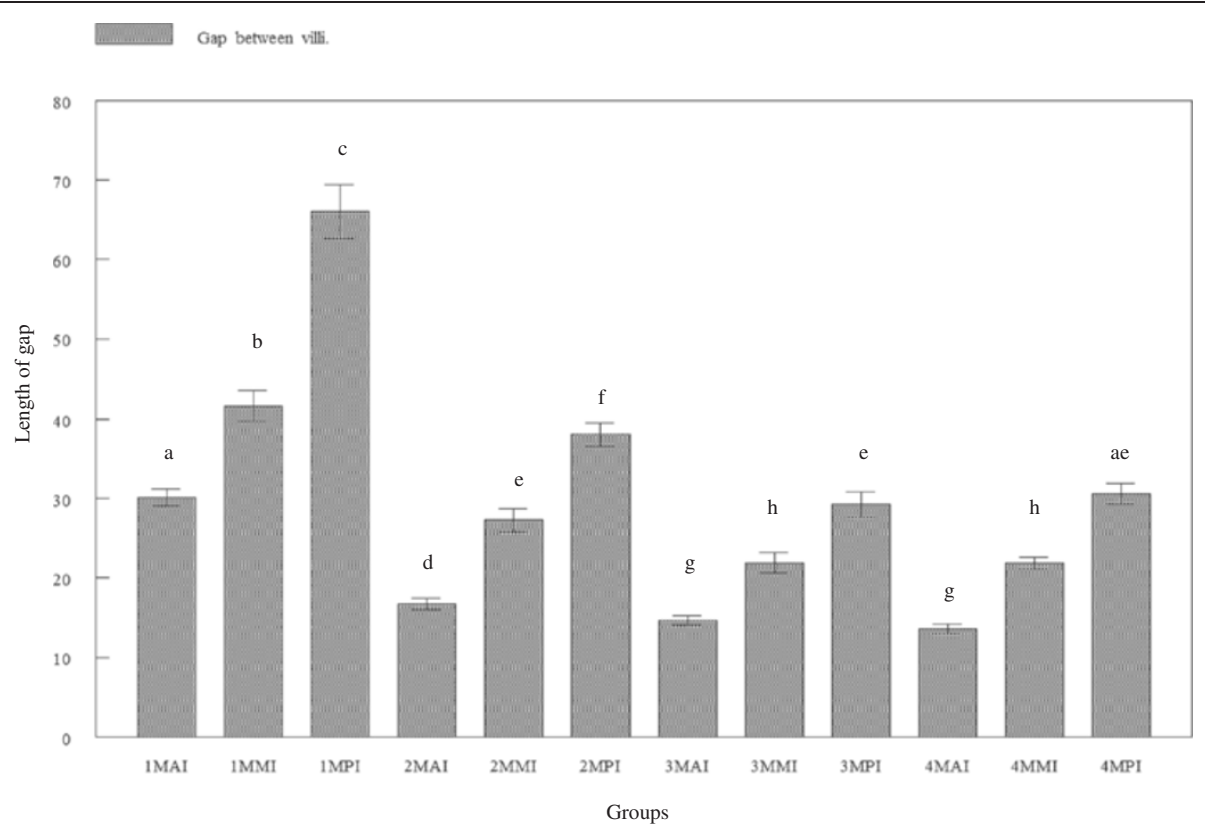

Figure 5 Cross-section of mid intestine of 120 days old tiger grouper showing intermediately tall villi with lamina propria (arrows) that is thicker than anterior intestine but thinner than the posterior intestine $(H \& E \times 40)$.

respectively. The average gap between villi of the posterior intestine was $66.024 \pm 13.096,38.078 \pm 5.7424,29.258 \pm$ 6.1213 and $30.604 \pm 4.9327 \mu \mathrm{m}$, respectively.

Villus gap in the posterior region was significantly $(\mathrm{p}<0.05)$ wider than the mid and anterior regions. In all regions of the intestine, the gap was gradually and significantly $(\mathrm{p}<0.05)$ decreasing with increasing age of tiger grouper, except between 30 and 60 days old tiger groupers (Figure 6).

\section{Thickness of lamina propria}

Lamina propria in the anterior region was found to be significantly $(\mathrm{p}<0.05)$ thin, followed by the mid region and significantly $(\mathrm{p}<0.05)$ thick at the posterior region.

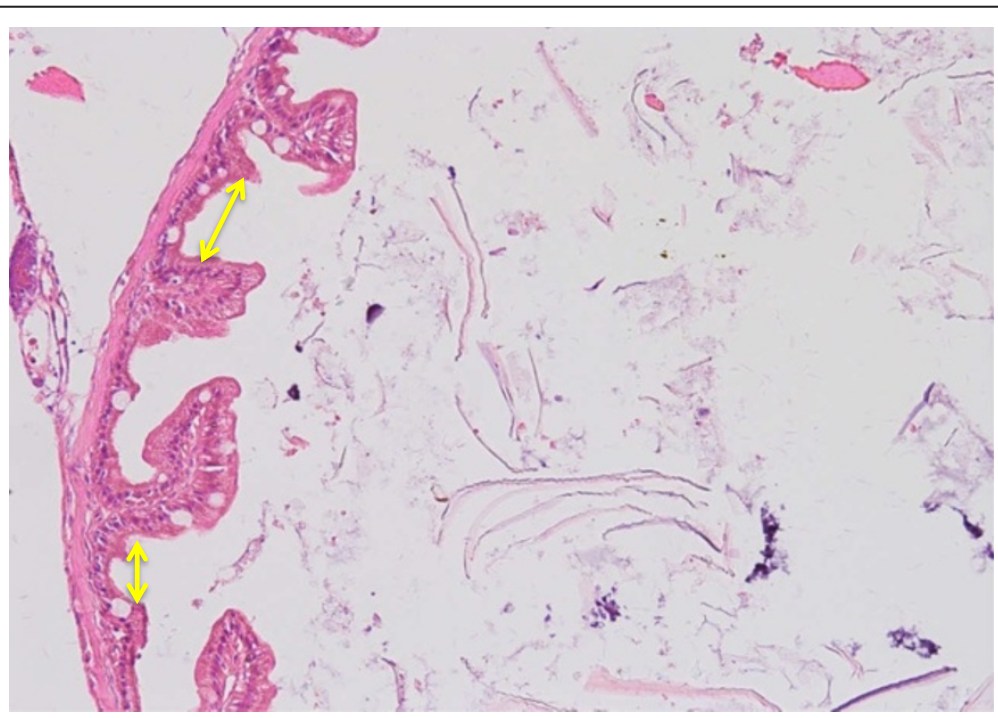

Figure $\mathbf{6}$ Cross-section of anterior intestine of $\mathbf{3 0}$ days old tiger grouper. The size of gap between villi in 30 days old tiger grouper is wide (arrows) and reduces when age is increase (H\&E x20). 
This was observed in all groups of tiger groupers (Figure 7). The average thickness of lamina propria at the anterior intestine was $14.854 \pm 3.7412,24.197 \pm 3.9502,25.889 \pm$ 4.2674 and $25.792 \pm 2.8590 \mu \mathrm{m}$ for tiger groupers at 30,60 , 90 and 120 days old, respectively. The average thickness of lamina propria at the mid intestine was $22.435 \pm 3.4695$, $31.094 \pm 5.0122,33.002 \pm 5.7754$ and $33.514 \pm 3.8933 \mu \mathrm{m}$ at 30, 60, 90 and 120 days old, respectively (Figure 8). The average thickness of lamina propria at the posterior intestine was $27.947 \pm 6.9433,34.598 \pm 7.6659,38.509 \pm 7.6971$ and $39.415 \pm 7.1762 \mu \mathrm{m}$, respectively.

The thickness of lamina propria in all regions of intestine was observed to gradually increased with age. However, significant $(\mathrm{p}<0.05)$ difference in the thickness of lamina propria was only observed between 30 days old and other groups of 60,90 and 120 days old tiger grouper in all regions of intestine. The differences in thickness of lamina propria among 60, 90 and 120 days old tiger grouper was found insignificant $(\mathrm{p}>0.05)$ in all regions of the intestine.

\section{Numbers of lymphoid cells}

The numbers of lymphoid cells in the lamina propria were found to differ between the different intestinal regions. Significantly $(p<0.05)$ highest average number of lymphoid cells was found in the posterior intestine followed by the mid and the anterior intestines of all age groups (Figures 9 and 10). The average number of lymphoid cells in the anterior intestine was $18.867 \pm 6.1975$, $52.867 \pm 10.218,83.400 \pm 14.657$ and $150.40 \pm 25.972 \mu \mathrm{m}$ for tiger groupers at 30 days, 60 days, 90 days and 120 days old, respectively. The average number of lymphoid cells in the mid intestine was $22.600 \pm 3.8508,65.933 \pm 10.807$, $107.53 \pm 17.635$ and $192.67 \pm 35.826 \mu \mathrm{m}$ at 30 days, 60 days, 90 days and 120 days old, respectively. The average number of lymphoid cells in the posterior intestine was $32.867 \pm 8.1141,97.600 \pm 28.362,145.33 \pm 26.300$ and $268.07 \pm 52.138 \mu \mathrm{m}$, respectively.

The numbers of lymphoid cells in lamina propria were significantly $(\mathrm{p}<0.05)$ highest in the posterior region, followed by the mid region and least in the anterior region. The number of lymphoid cells in the intestine of 30 days old tiger groupers was significantly $(\mathrm{p}<0.05)$ lower than other studied ages. Similarly, the average number of lymphoid cells in the intestine of 60 days old was significantly $(\mathrm{p}<0.05)$ lower than the 90 days old, which was significantly $(\mathrm{p}<0.05)$ lower than the 120 days old (Figure 9). The number of lymphoid cells in all intestinal regions was observed to gradually increase with age.

\section{Number of goblet cells}

At the early age, goblet cell counts showed no significant $(p>0.05)$ differences in all regions of the intestine as observed in the 30 and 60 days old tiger grouper (Figures 11 and 12). The 30 days old groupers had an average number of $11.467 \pm 3.2704,13.000 \pm 2.4785$ and $13.067 \pm 2.5204$ cells in the anterior, mid and posterior intestines, respectively compared to $13.200 \pm 2.9568$, $14.600 \pm 2.9228$ and $14.133 \pm 2.3258$ cells in the anterior, mid and posterior intestines of 60 days old groupers, respectively.

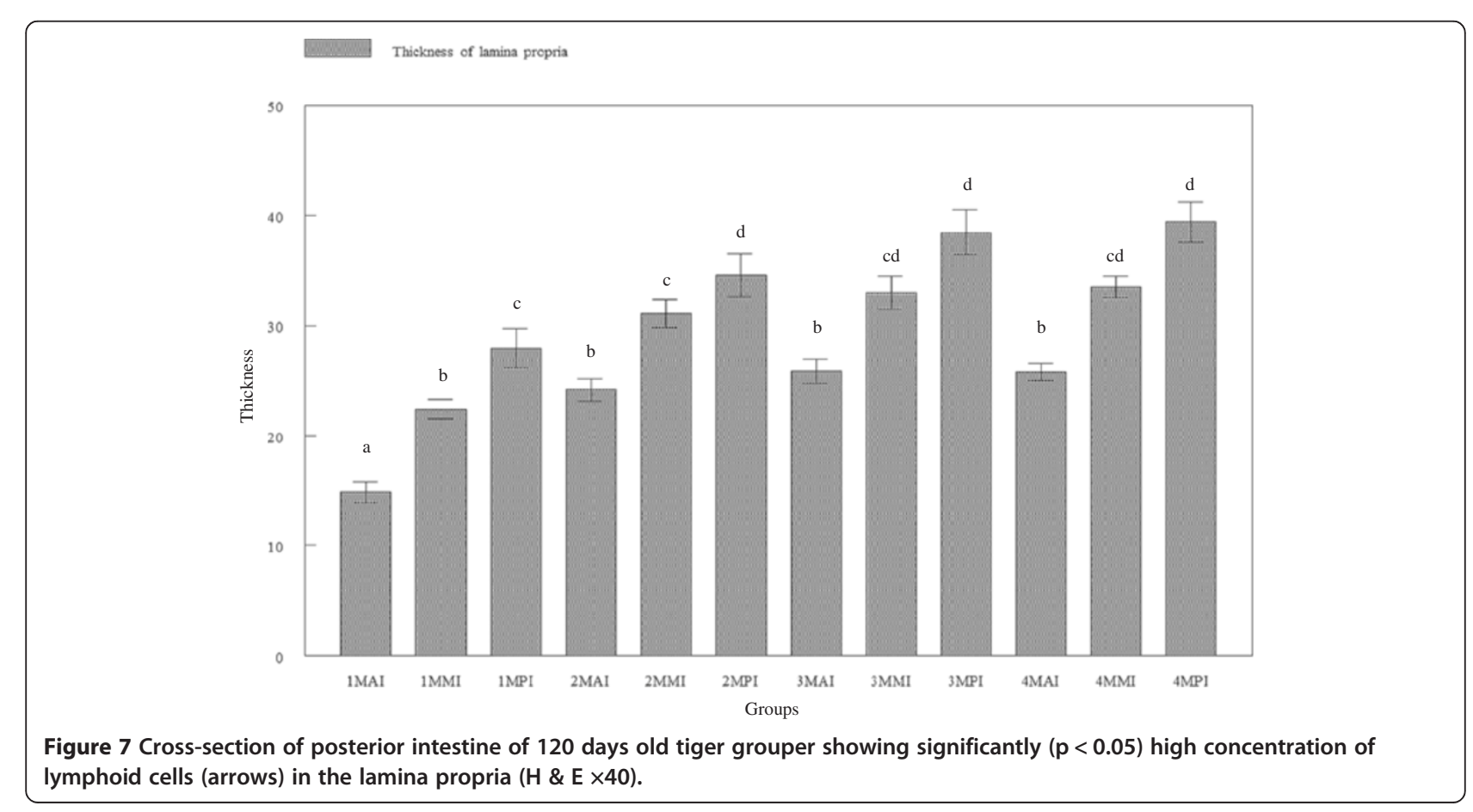




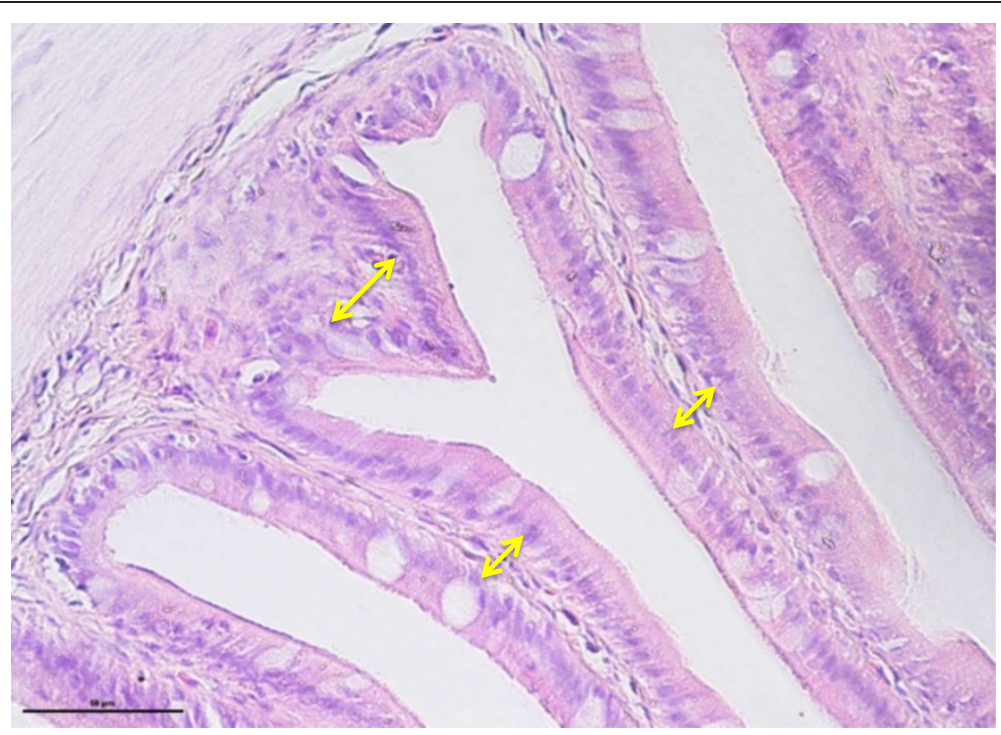

Figure $\mathbf{8}$ Cross-section of mid intestine of $\mathbf{1 2 0}$ days old tiger grouper. The thickness of lamina propria in mid intestine (arrows) are thinner than posterior but thicker than anterior ( $H \& E \times 40)$.

However, the number of goblet cells started to significantly $(\mathrm{p}<0.05)$ increased at the age of 90 days old with $54.200 \pm 6.2929$ cells in the anterior intestine, $77.733 \pm 10.117$ cells in the mid and $80.600 \pm 9.2257$ cells in the posterior intestines. The incremental pattern continued in the 120-day old tiger groupers with
$116.07 \pm 14.733$ cells in the anterior, $141.00 \pm 22.548$ cells in the mid and $112.00 \pm 29.653$ cells in the posterior intestines. The number of goblet cells in all regions of the 90-day old tiger grouper was significantly $(\mathrm{p}<0.05)$ less than the 120 -day old tiger groupers (Figure 11).

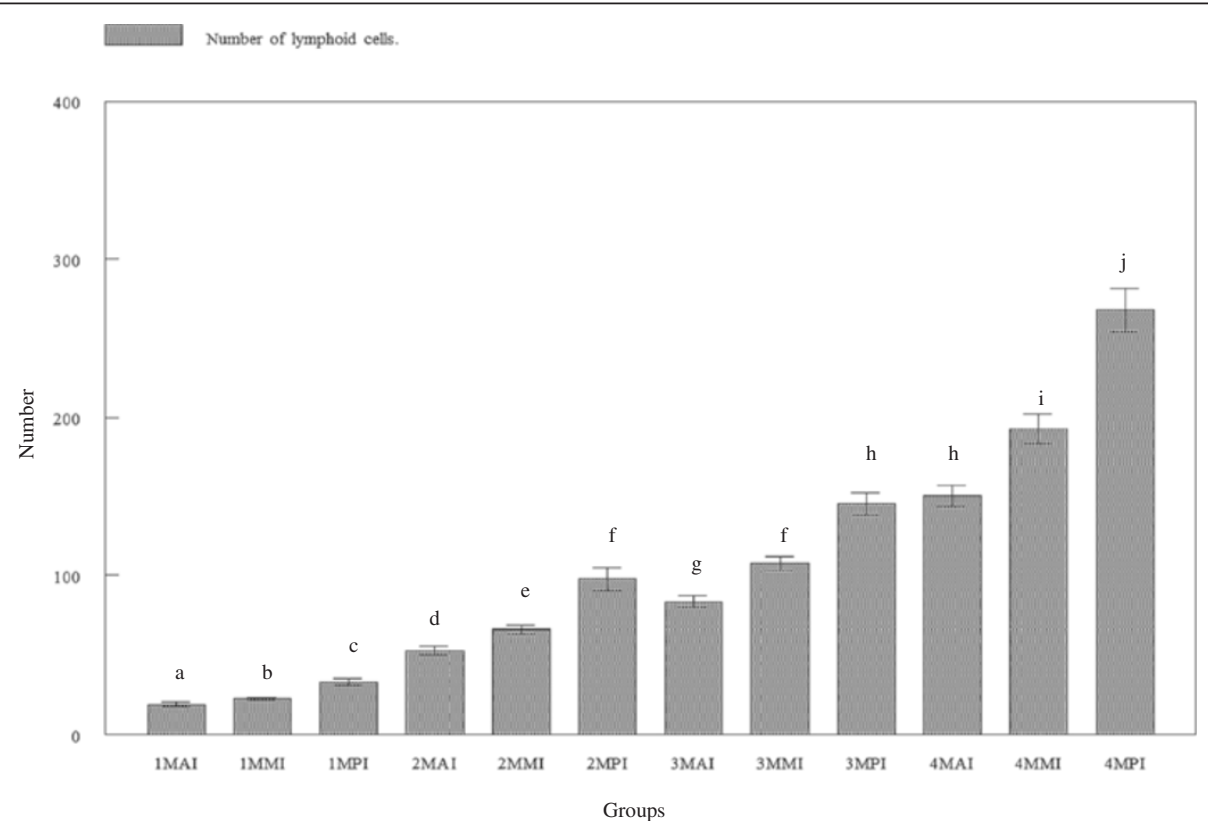

Figure 9 Number of goblet cells in lamina propria of three regions of tiger grouper intestine; anterior intestine (AI), mid intestine (IM) and posterior intestine $(\mathrm{PI})$, in four experimental ages; 30 days $(1 \mathrm{M}), 60$ days $(2 \mathrm{M}), 90$ days $(3 \mathrm{M})$ and 120 days $(4 \mathrm{M})$. 


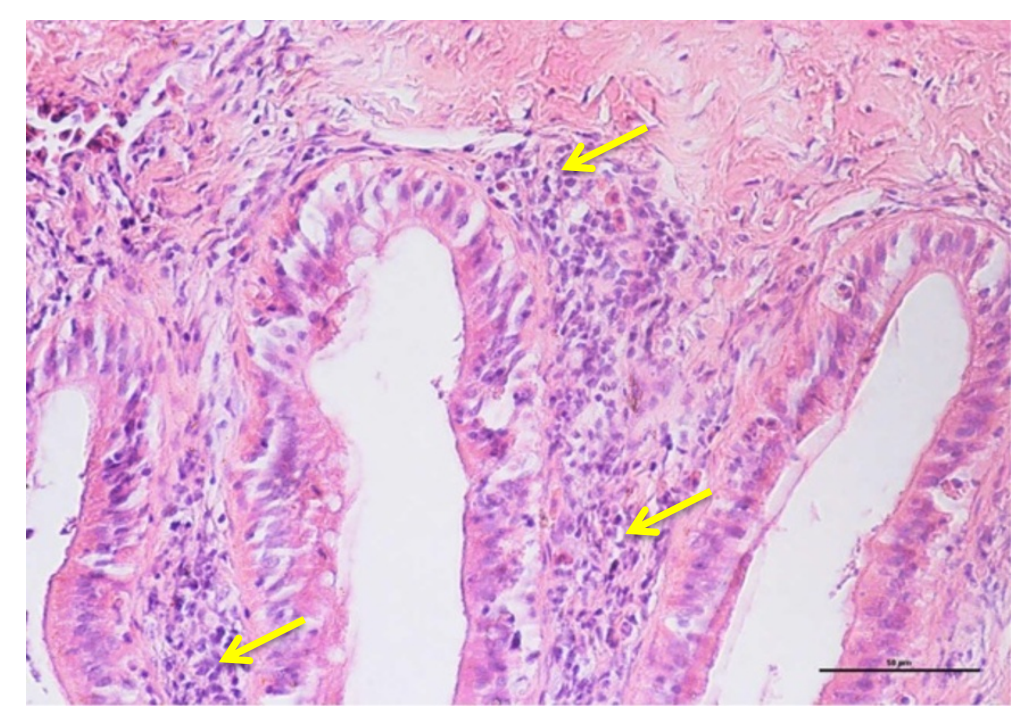

Figure 10 Cross-section of posterior intestine of 120 days old tiger grouper. High concentration of lymphoid cells found scattered in lamina propria of posterior intestine (arrows) (H\&E X40).

\section{Thickness of intestinal muscle}

The growth of intestinal muscles was found to be slow in the first three months before drastically increased at the age of 120 days old (Figure 13). At 30 days, the thickness of muscular layer of the anterior intestine was $18.242 \pm$ $5.2238 \mu \mathrm{m}$, which was significantly $(\mathrm{p}<0.05)$ thicker than the mid $(12.387 \pm 3.7875 \mu \mathrm{m})$ and posterior $(12.637 \pm$ $3.3883 \mu \mathrm{m})$ regions (Figure 14). At the ages of 60 and
90 days old, muscle thickness at the anterior regions $(32.717 \pm 9.5340 \mu \mathrm{m}$ and $61.287 \pm 18.161 \mu \mathrm{m}$, respectively) was significantly $(\mathrm{p}<0.05)$ thicker than the mid regions $(27.053 \pm 7.6956 \mu \mathrm{m}$ and $37.535 \pm 6.8394 \mu \mathrm{m}$, respectively), but not significant $(\mathrm{p}>0.05)$ than the posterior regions (35.241 $\pm 11.660 \mu \mathrm{m}$ and $62.425 \pm 20.315 \mu \mathrm{m}$, respectively). However, observation in 120 days old tiger groupers revealed the intestinal muscle to be thickest at the anterior

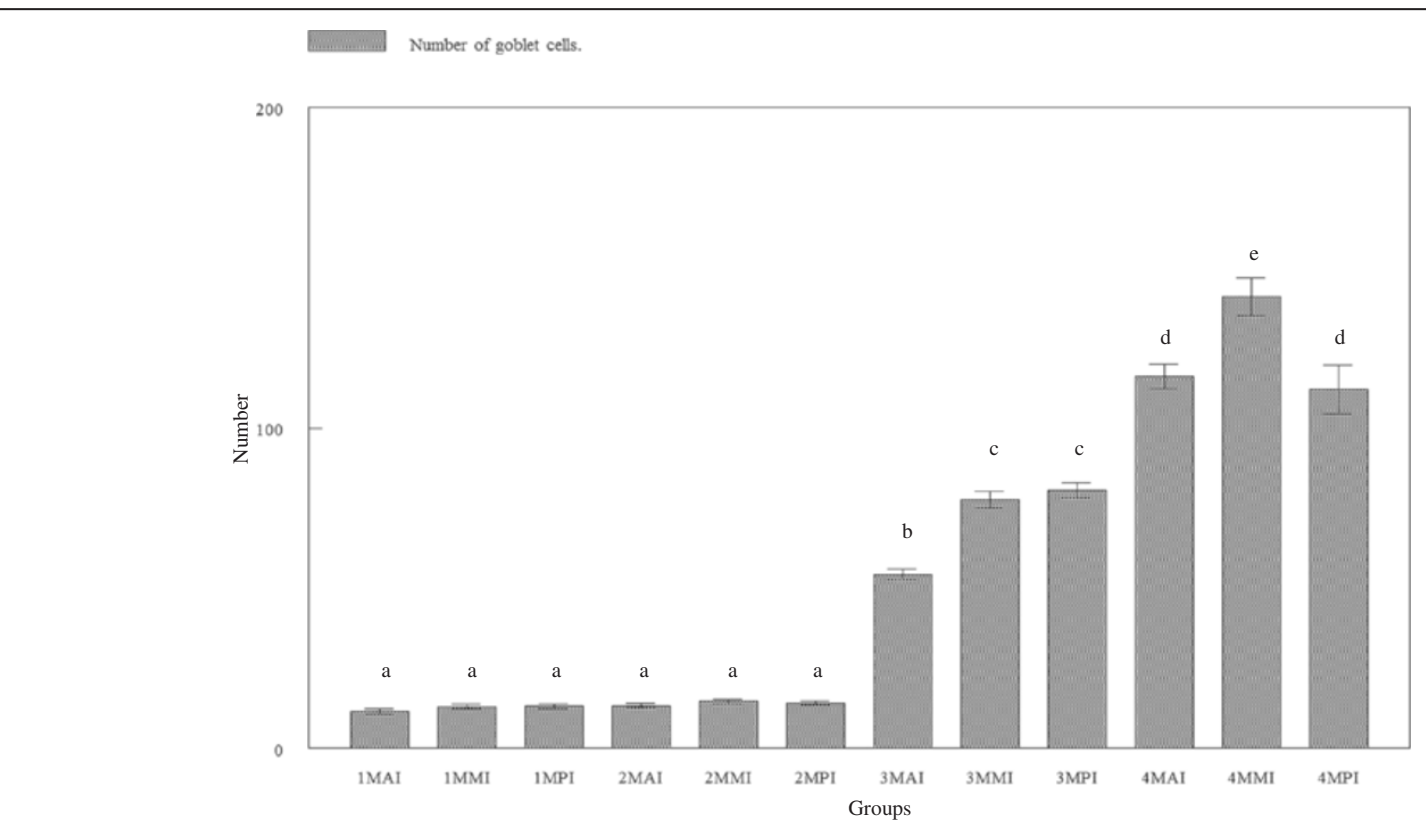

Figure 11 Number of goblet cells in lamina propria of three regions of tiger grouper intestine; anterior intestine (AI), mid intestine (IM) and posterior intestine (PI), in four experimental ages; 30 days (1M), 60 days (2M), 90 days (3M) and 120 days (4M). 


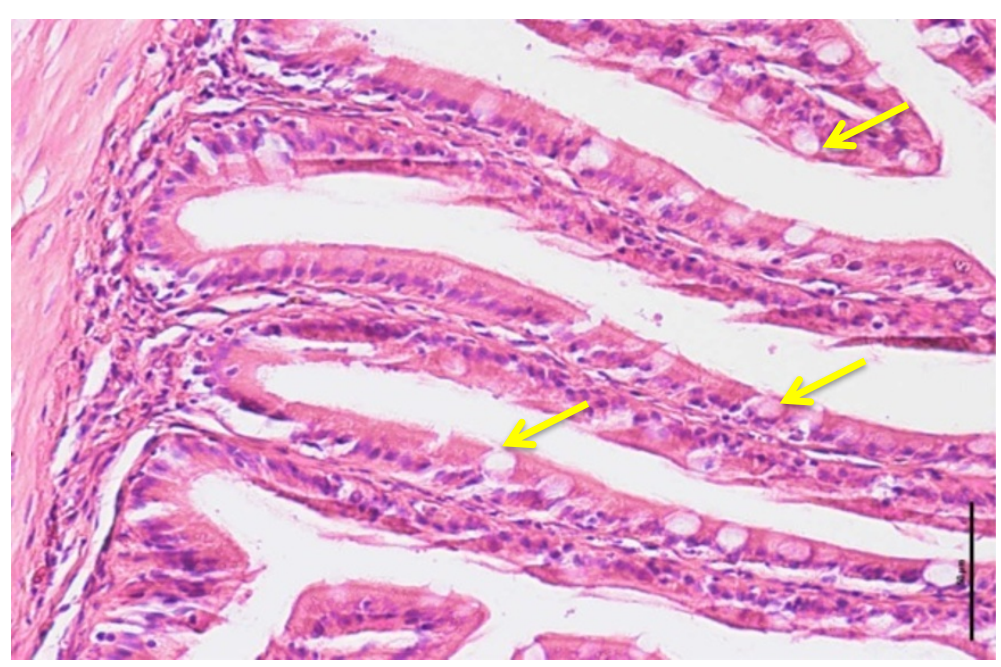

Figure 12 Cross-section of anterior intestine of $\mathbf{9 0}$ days old tiger grouper. Goblet cells (arrows) found in every regions of intestine (H\&E $\times 40)$.

region $(271.02 \pm 57.174 \mu \mathrm{m})$, followed by the posterior region $(196.35 \pm 23.115 \mu \mathrm{m})$ and thinnest in the mid region $(123.72 \pm 42.411 \mu \mathrm{m})$.

Generally, the thickness of intestinal muscle gradually increased with age. The thickness of 30 days old tiger grouper was significantly $(\mathrm{p}<0.050$ less than the 60 days old, which was significantly $(\mathrm{p}<0.05)$ less than the 90 days old and significantly $(\mathrm{p}<0.05)$ less than the 120 days old tiger groupers.

\section{Correlations}

The number of villi (0.9097), the length of villi $(0.9246 \mu \mathrm{m})$, the number of lymphoid cells (0.9343), the thickness of lamina propria $(0.6621 \mu \mathrm{m})$, the number of goblet cells (0.9178) and the thickness of intestinal muscle $(0.8262 \mu \mathrm{m})$ of the anterior intestine showed direct proportionate to the age of tiger grouper and between each other. Only the gap between villi $(-0.7994 \mu \mathrm{m})$ was inversely proportional to the age and other parameters (Additional file 1: Table S1).

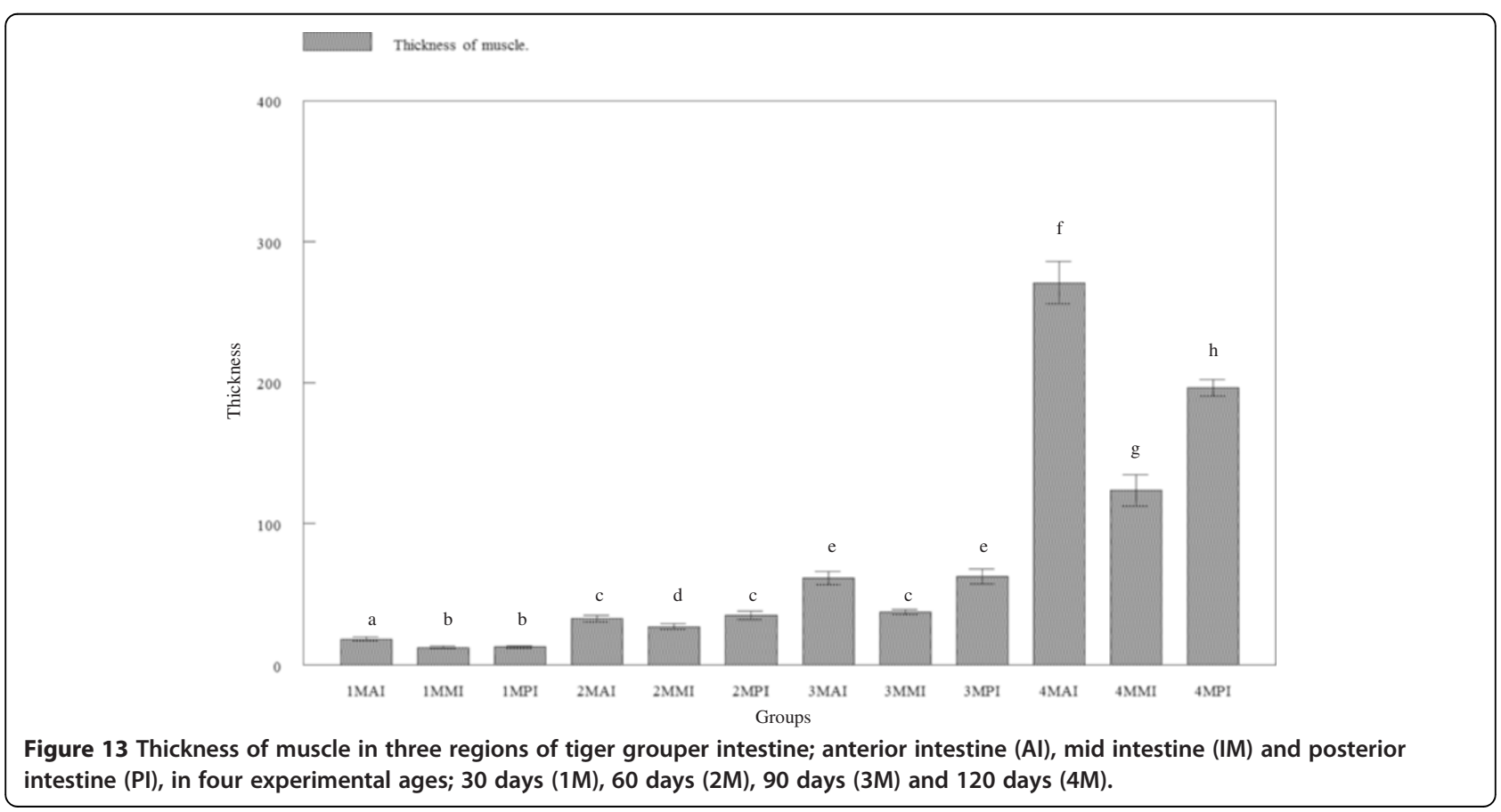




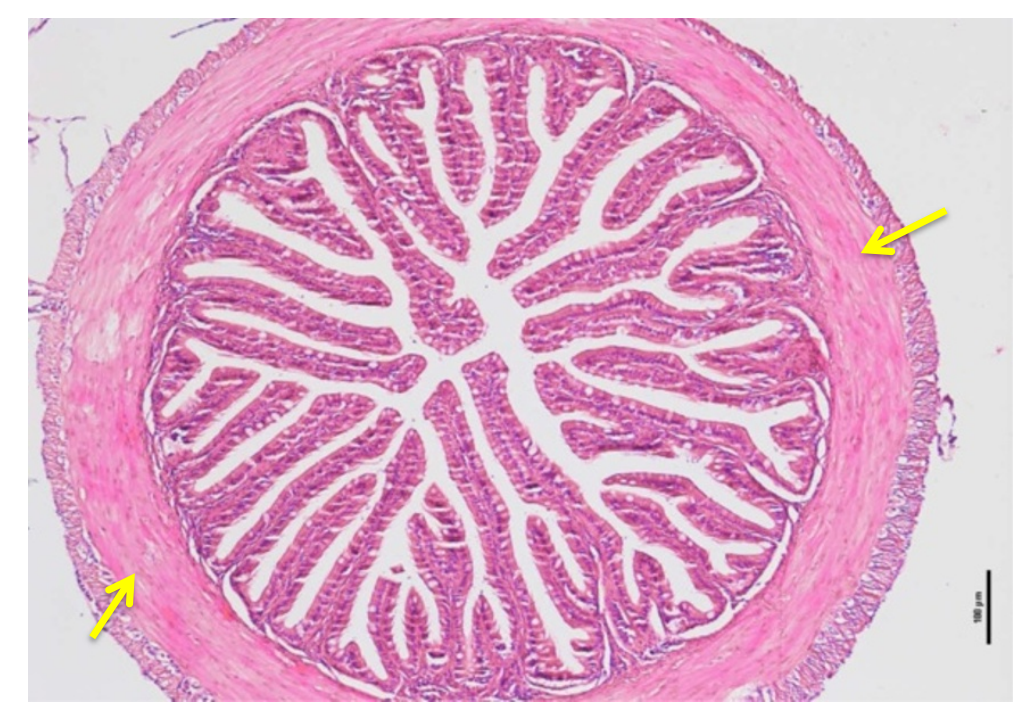

Figure 14 Cross-section of anterior intestine of $\mathbf{9 0}$ days old tiger grouper. The thickest muscle (arrows) found in anterior region of intestine (H\&E x10).

Similar correlations were observed in the mid (Additional file 2: Table S2) and posterior (Additional file 3: Table S3) intestines.

\section{Discussion}

Intestine is a tubular organ where feed from stomach passes through to start an alkaline digestion before the nutrient absorption (Canan et al., 2012). Unlike mammals, there are no distinct separation between small and large intestines of teleost fish (Albrecht et al., 2001). In other word, the intestine is just an undifferentiated tube. Furthermore, the intestine of teleost did not reveal obvious crypts of Lieberkuhn that normally found in mammals. However, Wallace et al. (2005) divided the intestine into three regions namely the anterior, mid and posterior regions.

The intestinal epithelium is a single-cell layer from the type of absorptive columnar cells or enterocytes, which play a role in protecting the fish against harmful agents in lumen. It also functions as a site for nutrient, water and ion uptake (Sundell et al., 2003). In fish, the length of intestine varies and depends on the diet, but basically between 0.4 and 38 times longer than the body length. The amount of plant materials in diet is the major determination factor for intestinal length. Usually, herbivorous fish have longer intestine compared to carnivorous fish (Clements and Raubenheimer, 2006).

This study elaborates the evolution of intestinal tissues and cells of tiger grouper from the age of 30 days until 120 days, which included the villi, lamina propria, lymphoid cells, goblet cells and muscle tissues. Villi are small, finger-like projections that protrude from the epithelial lining of the intestinal wall. Villi are specialized tissues, created to do the absorption in the small intestine as they have a thin wall, about one-cell thick known as enterocyte that enables a shorter diffusion path (Ferraris et al., 1990; Oxley et al., 2007). They also have a large surface area due to their 'loops-like' shape, for more efficient absorption of nutrients into the blood stream (Bakke et al., 2011). The complete shape and function of villi could be observed in as early as 30 days old tiger grouper for absorption of smaller and solubilized nutrients.

The numbers of villi in the anterior intestine were significantly high since it is the place where mechanically digested feeds or chyme from the stomach started to be absorbed, just like the first filter that filtrate maximum amount of digested feed particles from the stomach. Therefore, the maximum numbers of villi are needed to do the maximum absorption job (Bakke et al., 2011). Similarly, the lengths of villi in anterior intestine were significantly taller. This was to provide more surface area for absorption of nutrient-rich feed particles more efficiently (Nordrum et al., 2000; Bakke et al., 2010). This was in agreement with the conclusion that absorption of nutrients such as protein, carbohydrate and lipid occurred at a faster rate in proximal or anterior regions of intestine (Collie, 1985; Buddington and Diamond 1987; Dabrowski, 1990; Bakke-McKellep et al., 2000; Jutfelt et al., 2007).

The remnants of feed particles that are not absorbed in the anterior intestine then migrate into mid intestine where absorption process continues to occur. Since the amounts of feed particles that migrate toward mid intestine are lesser, the number and length of villi were significantly reduced. Finally, the remaining unabsorbed feed particles and wastes migrate into posterior intestine, waiting to be removed from the body through anus that 
is located at the end of posterior intestine. Thus, the function of posterior intestine or hindgut is more to immunity than to absorption process (Ezeasor and Stokoe 1981; Buddington and Diamond, 1987). Since the feed demand and consumption increase with age of fish, the number and length of villi keep increasing with age of the tiger grouper.

The lamina propria is a vascularized connective tissue containing nerves and leukocytes, which lies beneath the epithelium and together with the epithelium constitutes the mucosa (Wilson and Castro, 2011). The thickness of lamina propria in anterior intestine was significantly less than the mid intestine but became significantly thicker in the posterior intestine. Therefore, the thickness of lamina propria was inversely proportional with the number of villi. The rapid growth and development of the lamina propria occurred between 30-day and 60-day old groupers when significant increase in the thickness of lamina propria was observed.

This study also revealed that the thickness of lamina propria was related with the concentration of lymphoid cells and the region's specific function. High concentrations of lymphoid cells were observed in the posterior intestine, and support the conclusion that posterior intestine plays a major role in immunity (Buddington and Diamond, 1987). Similarly, Ezeasor and Stokoe (1981) found high phagocytic activities in the posterior intestine compared to another regions while a study in red tilapia revealed accumulation of lymphoid cells in the lamina propria of posterior intestine following oral vaccination with adjuvanted feed-base vaccine against streptococcosis (Firdaus-Nawi et al., 2012). Due to the immunity functions but less nutrient absorptive capacity (Buddington and Diamond, 1987), posterior intestine requires large numbers of lymphoid cells and the lamina propria should be thick to provide enough space for the lymphoid cells.

The thickness of lamina propria and number lymphoid cells were significantly reduced in the mid intestine. Although the function of mid intestine is not well understood, it was suggested that mid intestine moderately play both absorption and immunity roles. Mid intestine completes the absorption process that was previously done by anterior intestine and starts the immune response prior to the posterior intestine. The presence of lymphoid and goblet cells in intestines of 30-day old tiger grouper indicated that intestinal immunity was present at that particular age. This is in agreement with previous study by Lin et al. (2007) in 19-day old groupers where oral immunization with inactivated nervous necrosis virus (NNV) provided good protection after challenge with live NNV.

Empty space between two villi is called villous gap that appears to be influenced by the number of villi. Size of the gap in region that was packed with villi, such as the anterior intestine, was narrower than the size in mid and posterior intestines where the number of villi was less.
The function of the villous gap is to provide spaces for food particles to be absorbed by the villi. Therefore, the gap in 30 days old tiger grouper was significantly larger due to the feeding behavior where young tiger grouper usually consume less food.

Goblet cells are glandular simple columnar epithelial cells and the major mucous cell type in the intestine of fishes (Wilson and Castro, 2011). The main function of goblet cells is to secrete mucin that dissolves in water to form mucus, a clear, colorless and slimy substance that creates a layer to coat the wall of intestine (Kim and Samuel, 2010). Besides function as a lubricant for smooth movement of feed particles, mucus also provides innate host defense by acting as a first line of immunity against invasion of harmful pathogen (Kim and Samuel, 2010). Intestinal mucus secreted in fish contains antibody (Grabowski et al., 2004; Firdaus-Nawi et al., 2012), lysozyme (Lie et al., 1989), glycoprotein (Shephard, 1994), complement components, lectins and some antimicrobial agents (Ingram, 1980; Alexander and Ingram, 1992). In this study, goblet cells were found scattered among the epithelial lining in all three regions of the intestine, but showed no significant difference in numbers until 90 days old. Between 90 and 120 days old, the numbers of goblet cells in mid intestine were dramatically increased, suggesting the important nonspecific or innate immunity role played by the region. Therefore, the innate immune system in the mid intestine detects and prevents the presence of invasive pathogen prior to stimulation of the specific immune system in the posterior intestine.

Teleost intestines are lack of muscularis mucosa that divides lamina propria from sub-mucosa (Wallace et al., 2005). The development of intestinal muscle can be attributed to the feeding regime. From birth to the age of 40 days old, tiger grouper were fed with live feed since their digestion system; particularly due to intestinal muscle which less developed. This makes oral vaccination via live feed possible for juvenile groupers At the age of 40 days old and above, they were fed with larvae pellet where the intestinal muscle became thicker as observed in the 60 and 90 days old tiger groupers. Largesized pellet was introduced to the tiger grouper at the age of 100 days, thus the thickest muscular layer was observed in tiger grouper at age 120 days old.

\section{Conclusion}

From the study, we have found the intestinal immunity in tiger grouper is existed as early as thirty days old age, and every region of intestine have different roles either in food processing or immunity. Since the intestinal immunity is existed at the age of thirty days old, vaccination could be conducted at that particular age. However, vaccination at 60-day old is expected to stimulate stronger immune response since the immune cells were well establsihed. 


\section{Additional files}

Additional file 1: Table S1. Correlation (Pearson) value between each studied parameters in anterior intestine, age of tiger grouper (AGE), gap between villi (GBV), thickness of lamina propria (TLP), length of villi (LOV), number of goblet cells (NGC), number of villi (NOV), number of lymphoid cells (NLC) and thickness of muscle (TOM).

Additional file 2: Table S2. Correlation (Pearson) value between each studied parameters in mid intestine, age of tiger grouper (AGE), gap between villi (GBV), thickness of lamina propria (TLP), length of villi (LOV), number of goblet cells (NGC), number of villi (NOV), number of lymphoid cells (NLC) and thickness of muscle (TOM).

Additional file 3: Table S3. Correlation (Pearson) value between each studied parameters in posterior intestine, age of tiger grouper (AGE), gap between villi (GBV), thickness of lamina propria (TLP), length of villi (LOV), number of goblet cells (NGC), number of villi (NOV), number of lymphoid cells (NLC) and thickness of muscle (TOM).

\section{Competing interests}

The authors declare that they have no competing interests.

\section{Authors' contribution}

MFN has carried out the research work and analyzed the date, MZS outlined the research design and supervised the experimental trial, MZAB and MEAW helped revised the project and read the manuscript. All authors read and approved the final manuscript.

\section{Acknowledgement}

The authors wish to thank the Marine Aquaculture Breeding Technology Centre, Tanjung Demong, Terengganu, Malaysia for fish supply and facilities for conducting this study. We thank Ahmad Baihaqi Othman and Dr. Siti Zahrah Abdullah for their technical assistance and advice.

\section{Author details}

${ }^{1}$ Faculty of Veterinary Medicine, Universiti Putra Malaysia, Serdang, Selangor 43400, Malaysia. ${ }^{2}$ Marine Finfish Production and Research Centre, FRI Tanjung Demong, Besut, Terengganu 22200, Malaysia. ${ }^{3}$ Institute of Marine Biotechnology, Universiti Malaysia Terengganu, Kuala Terengganu, Terengganu 21030, Malaysia.

Received: 3 October 2013 Accepted: 7 November 2013

Published: 15 November 2013

\section{References}

Afero F, Miao S, Perez AA (2009) Economic analysis of tiger grouper Epinephelus fuscoguttatus and humpback grouper Cromileptes altivelis commercial cage culture in Indonesia. Aquac Int, doi:10.1007/s10499- 009-9295-x

Albrecht MP, Ferreira MFN, Caramaschi EP (2001) Anatomical features and histology of the digestive tract of two related neotropical omnivorous fishes (Characiformes; Anostomidae). J Fish Biol 58(2):419-430

Alexander JB, Ingram GA (1992) Noncellular nonspecific defense mechanism of fish. Annu Rev Fish Dis 2:249-279

Aranishi F, Mano N (2000) Antibacterial cathepsins in different types of ambicoloured Japanese flounder skin. Fish Shellfish Immunol 10:87-89

Bakke AM, Tashiian DH, Wang CF, Lee SH, Bai SC, Hung SS (2010) Competition between selenomethionine and methionine absorption in the intestinal tract of green sturgeon (Acipenser medirostris). Aquat Toxicol 96(1):62-69

Bakke AM, Glover C, Krogdahl A (2011) Feeding, digestion and absorption of nutrients. In: Grosell M, Farrell AP, Brauner CJ (eds) The multifunctional gut of fish. Academic Press, USA, pp 57-75

Bakke-McKellep AM, Nordrum S, Krogdahl A, Buddington RK (2000) Absorption of glucose, amino acids, and dipeptides by the intestines of Atlantic salmon (Salmo salar L.). Fish Physiol Biochem 22:33-44

Buddington RK, Diamond JM (1987) Pyloric ceca of fish: A "new" absorptive organ. Am J Physiol 252:G65-G76

Buddington RK, Kuz'mina V (2000) Digestive system. In: The laboratory fish. Academic Press, USA, pp 173-179

Cain KD, LaPatra SE, Baldwin TJ, Shewmaker B, Jones J, Ristow SS (1996) Characterization of mucosal immunity in rainbow trout Oncorhynchus mykiss challenged with infectious hematopoietic necrosis virus: identification of antiviral activity. Dis Aquat Organ 27:161-172

Cain KD, Jones DR, Raison RL (2000) Characterization of mucosal and systemic immune responses in rainbow trout (Oncorhynchus mykiss) using surface plasmon resonance. Fish Shellfish Immunol 10:651-666

Canan B, Do Nascimento WS, Da Silva NB, Chellappa S (2012) Morphohistology of the digestive tract of the damsel fish Stegastes fuscus (Osteichthyes: Pomacentridae). The Scientific World Journal Article ID 787316:9, doi:10.1100/2012/787316

Clements KD, Raubenheimer D (2006) Feeding and Nutrition. In: Evans DH, Claiborne JB (eds) The physiology of fishes. Taylor and Francis Group, Boca Raton, FL, USA

Cole AM, Weis P, Diamond G (1997) Isolation and characterization of pleurocidin, an antimicrobial peptide in the skin secretions of winter flounder. J Biol Chem 272:12008-12013

Collie NL (1985) Intestinal nutrient transport in coho salmon (Oncorhynchus kisutch) and the effects of development, starvation, and seawater adaptation. J Comp Physiol B 156:163-174

Concha MI, Molina S, Oyarzun C, Villanueva J, Amthauer R (2003) Local expression of apolipoprotein A-I gene and a possible role for $\mathrm{HDL}$ in primary defence in the carp skin. Fish Shellfish Immunol 14:259-73

Dabrowski K (1990) Absorption of ascorbic acid andascorbic sulfate and ascorbate metabolism in stomachless fish, Common carp. J Comp Physiol B 160:549-561

Dalmo RA, Ingebrightsen K, Bogwald J (1997) Non-specific defense mechanisms in fish, with particular reference to the reticuloendothelial system (RES). J Fish Dis 20:241-273

De Silva SS (1998) Tropical Mariculture: Current Status and Prospects. Trop Mariculture 1:1-16

Ellis AE (2001) The immunology of teleosts. In: Roberts RJ (ed) Fish Pathology. WB Saunders, London, pp 133-150

Ezeasor DN, Stokoe WM (1981) Light and electron microscopic studies on the absorptive cells of the intestine ceca and rectum of the adult rainbow trout, Salmo gairdneri. J Fish Biol 18:527-544

Federal Agricultural Marketing Authority of Malaysia (2013) National Agro-food Policy 2010-2020., Accessed on October 26, 2013 at http://www.fama.gov. my/en/dasar-agromakanan-negara-2011-2020-dan-\#.UpSxQo0Vg3Y

Fernandes JMO, Kemp GD, Smith VJ (2004) Two novel muramidases from skin mucosa of rainbow trout (Oncorhynchus mykiss). Comp Biochem Physiol B 138:53-64

Ferraris RP, Yasharpour S, Lloyd KC, Mirzayan R, Diamond JM (1990) Luminal glucose concentrations in the gut under normal conditions. Am J Physiol 259:G822-G837

Firdaus-Nawi M, Sabri MY, Hanan Y, Siti-Zahrah A, Zamri-Saad S (2012) Efficacy of feed-based adjuvant vaccine against Streptococcus agalactiae in Oreochromis spp. in Malaysia. Aquacult Res, In Press (Early view) doi:10.1111/ j.1365-2109.2012.03207.x

Fletcher TC, Grant PT (1968) Glycoproteins in the external mucous secretions of the plaice, Pleuronectes platessa and some other fishes. Biochemistry 106:12

Food and Agriculture Organization (FAO) (2013) FAO Statistical Yearbook-World Food And Agriculture 2013. FAO Publishing, Food and Agriculture Organization of the United Nations, Rome, Italy, ISSN: 2225-7373

Grabowski LD, LaPatra SE, Cain KD (2004) Systemic and mucosal antibody response in tilapia, Oreochromis niloticus (L.), following immunization with Flavobacterium columnare. J Fish Dis 27:573-581

Heemstra PC, Randall JE (1993) FAO species catalogue, Groupers of the World (Family Serranidae, subfamily Epinephelinae): An Annotated and Illustrated Catalogue of the Grouper, Rockcod, Hind, Coral grouper and Lyretail species known to date, vol. 16FAO. FAO Publishing, Food and Agriculture Organization of the United Nations, Rome, Italy, ISSN: 0014-5602

Ingram GA (1980) Substances involved in the natural resistance of fish to infection-a review. Fish Biol 16:23-60

Jutfelt F, Olsen RE, Björnsson BTH, Sundell K (2007) Parr-smolt transformation and dietary vegetable lipids affect intestinal nutrient uptake, barrier function and plasma cortisol levels in Atlantic salmon. Aquaculture 273:298-311

Kim YS, Samuel BH (2010) Intestinal goblet cells and mucins in health and disease: recent insights and progress. Curr Gastroenterol Rep 12:319-330

Liao IC, Su HM, Chang EY (2001) Techniques in finfish larviculture in Taiwan. Aquaculture 200:1-31

Lie O, Sovensen A, Froysadal E (1989) Study on lysozyme activity in some fish species. Dis Aquat Organ 6:1-5 
Lin CC, Lin JHY, Chen MS, Yang HL (2007) An oral nervous necrosis virus vaccine that induces protective immunity in larvae of grouper (Epinephelus coioides). Aquaculture 268:265-273

Lindenstrøm T, Collins CM, Bresciani J, Cunningham CO, Buchmann K (2003) Characterization of a Gyrodactylus salaris variant: infection biology, morphology and molecular genetics. Parasitology 127:165-177

Marte CL (2003) Larviculture of marine species in Southeast Asia: Current research and industry prospects. Aquaculture 227:293-304

Nordrum S, Bakke-McKellep AM, Krogdahl A, Buddington RK (2000) Effects of soybean meal and salinity on intestinal transport of nutrients in Atlantic salmon (Salmo salar L.) and rainbow trout (Oncorhynchus mykiss). Comp Biochem Physiol B Biochem Mol Biol 125:317-335

Oxley A, Jutfelt F, Sundell K, Olsen RE (2007) Sn-2-monoacylglycerol, not glycerol, is preferentially utilised for triacylglycerol and phosphatidylcholine biosynthesis in Atlantic salmon (Salmo salar L.) intestine. Comp Biochem Physiol B 146:115-123

Shephard KL (1994) Functions for fish mucus. Biol Fish 4:473-485

Sugama K, Insan I, Koesshahrani I (2008) Hatchery and growth out technology of groupers in Indonesia. In: Liau IC, Leano EM (eds) The aquaculture of groupers. Word Aquaculture Society, USA, p 341

Sundell K, Jutfelt F, Augustsson T, Olsen R-E, Sandblom E, Hansen T, Björnsson BTH (2003) Intestinal transport mechanisms and plasma cortisol levels during normal and out of season parr-smolt transformation of Atlantic salmon, Salmo salar. Aquaculture 222:265-285

Toledo JD, Golez SN, Doi M (1996) Preliminary studies on the rearing of the redspotted grouper. Epinephelus coiodes larvae using copepod nauplii as initial food. UPV J Natl Sci 1:119-129

Tsutsui S, Tasumi S, Suetake H, Kikuchi K, Suzuki Y (2005) Demonstration of the mucosal lectins in the epithelial cells of internal and external body surface tissues in pufferfish (Fugu rubripes). Dev Comp Immunol 29(3):243-253

Wallace KN, Akhter S, Smith EM, Lorent K, Pack M (2005) Intestinal growth and differentiation in zebrafish. Mech Dev 122(2):157-173

Wilson JM, Castro LFC (2011) Morphological diversity of the gastrointestinal tract in fishes. In: Grosell M, Farrell AP, Brauner CJ (eds) The multifunctional gut of fish. Academic Press, USA, pp 2-44

Yashiro R (2008) Sperm cryopreservation of humpback grouper, Cromileptes altivelis (Valenciennes, 1828). Thai Fisheries Gazette, Thai National AGRIS Centre (Thailand), Main Library, Kasertsart University, PO Box 1084, Kasertsart Chatuchak, Bangkok 10903, Thailand

doi:10.1186/2193-1801-2-611

Cite this article as: Firdaus-Nawi et al:: Histological assessments of intestinal immuno-morphology of tiger grouper juvenile, Epinephelus fuscoguttatus. SpringerPlus 2013 2:611.

\section{Submit your manuscript to a SpringerOpen ${ }^{\circ}$ journal and benefit from:}

- Convenient online submission

- Rigorous peer review

- Immediate publication on acceptance

- Open access: articles freely available online

- High visibility within the field

- Retaining the copyright to your article

Submit your next manuscript at $\gg$ springeropen.com 